actuality, becomes a meaningful and inalienable part of social politics. These people need support, defence, help and caring from the side of the state in an order valuably to function in society, be not isolated from society and not to become a load for the wider public. Certainly, that exact and complete knowledge of features of the influence of social-psychological and biological factors on the process of ageing of personality, taking into account of gender aspects of social work with women and men years old will allow to the specialists of social sphere directionally to change terms, way of life of these people thus, to assist the optimal functioning of the personality of the man of senior age and render to the same retentive influence on the process of her ageing.

Key words: gender approach, gender peculiarities of ageing, gender-sensitive social work with older women and men.

\author{
UDC 372.881.1 \\ DOI https://doi.org/10.31392/NPU-nc.series5.2020.73-1.15
}

Hrachova I. V., Nikonenko O. V.

\title{
SUBSTANTIVATION OF USING PROJECT METHOD IN ENGLISH LANGUAGE TEACHING IN HIGHER EDUCATION INSTITUTIONS
}

The urgency of the study is the need to find the most effective methods of teaching English at practical classes in higher education institutions, so that teachers can improve English language skills of students, motivate students to study a foreign language, encourage their development. The purpose of the research is to prove the feasibility of using the project method while teaching English in higher education institutions to improve the educational process and the English language proficiency of cadets and students. Objectives of the study: to investigate the theoretical foundations of the problem; develop the tasks for practical classes using the method of projects in teaching English to students; determine the feasibility of using the project method in the teaching process. To substantiate the theoretical foundations of the study, analysis and generalization of literary sources on the topic, in particular, the analysis of teaching methods of the English language, have been used. The implementation of the project method in teaching English process in higher education institutions has been studied. The potential of this method is revealed, the expediency of its use at English language classes in higher education institutions is defined. The characteristics of the project method in teaching a foreign language have been presented, which can help teachers to use these methods in practice; and on their basis the fragments of lessons have been developed, that can serve as examples for the of collective and individual projects and studies use by teachers at English classes in higher education institutions. The methodology of projects has significant advantages over traditional methods in the interaction of students and teachers. Students become highly motivated and interested in the subject they work on during the project implementation. The teacher should direct and correct student activities, advise and inspire them. The concerted actions of the students with the teacher, aimed at achieving the goal the creation of the project, promote the improvement of mutual relations and deepening of mutual understanding between them.

Key words: project method, teaching methodology, higher educational institution, professional knowledge, intellectual activity, characteristics, teacher, student.

\section{(статтю подано мовою оригіналу)}

Relevance of research is the need to find the most effective methods of teaching English at practical classes in higher education institutions, so that you can improve the English language skills of higher education students, motivate them to study a foreign language, encourage their own development.

Purpose of the research: to prove the feasibility of using the project method in teaching English in higher education institutions to improve the educational process and increase the English language proficiency of cadets and students.

The project method is widely used in modern teaching of foreign languages in higher education institutions. Many researchers and methodologists have proved the effectiveness of using this method in theory and in practice (E. G. Arvanitopoulos, N. A. Glazkova, M. V. Nagachev, V. Kopylova, I. Oliynyk, E. S. Polat, S. O. Tsigankova, etc.) $[1 ; 3 ; 8 ; 9 ; 10 ; 11 ; 12]$.

The project method is an example of how it is possible to intensify the research, search, creative collective / individual work of students. The purpose of the projects is not only the result of students' work, but the organization and the process of carrying out the task themselves are important. Methodologists point out that this method involves the independent work of students, in which communication in a foreign language is combined with the emotional and intellectual component of another type of work (poll, television programs, newspapers, videos, etc.).

The creative component is an integral part of the project work. Students work together to find information to solve a particular problem. Thus, this type of activity induces them to transfer theoretical knowledge and skills to more practical type of activity. Students acquire creative competence that is combined with intellectual activity. By working on creative tasks to solve a problem, students can show their individuality, creativity, point of view, be active and independent even while working in a group.

Methodists distinguish the following types of projects that can be used in the educational process [9]:

- production projects. Students work on a project aimed at social interests of the group and achieve concrete results in the form of documents or materials (reports, exhibitions, presentations, videos, etc.); 
- research projects. Students are engaged in the search of information in a group or on their own, and the results of work are presented in the form of presentations, reports;

- projects-reviews. Students make questionnaires, conduct sociological surveys, analyze results;

- organizational-game projects. Students act in diverse roles, for example, celebrities (politicians, actors, writers, scientists), characters of films, books, fictional characters, etc.

The teacher should keep in mind certain requirements for the organization of the project work. First of all, this is a problematic issue that needs to be solved individually or in a group. The practical, theoretical, cognitive value of the results and the individual work of the students or in a team, at lessons and out of class should be determined. The content of the project should be structured, the results of phases and roles of group members should be given. The following research methods should be also used: the formulation of the problem issue, of the goal, the objectives of the study; consideration of the methodological foundations of the study, design and analysis of the results obtained, summing up the results, correcting them, if necessary, and conclusion. The project work has a certain structure and stages of holding:

- definition of the problem and theme of the project;

- distribution of roles of the group members;

- search and analysis of information;

- summarizing the results and presenting the project presentation.

The teacher chooses the options for a particular stage of the project and organizes the work of the students in such a way that their activities are at the center of attention in order to enable them to demonstrate their creativity, improve their communication skills in a foreign language, work in the team, and improve their practical skills. The project method enables students to try themselves as authors, artists, develop creative abilities, to expand not only the mind, but also improve their speech skills.

While working on projects, students are stepping up their work: they make presentations, take videos on specific subjects, search for the necessary data in literary sources and on the Internet, communicate with other people. Thus, the project method allows higher education graduates with different levels of language training to participate in project work, performing their functions according to their capabilities.

The teacher can use the project methodology in one or several English lessons for the presentation of any material on a specific topic. While developing their projects, higher education graduates may currently present their own ideas for setting up their upcoming companies, restaurants, schools, making magazines, sites, conducting social surveys, questionnaires, etc.

The method of projects is widely used in foreign language lessons, so that higher education students can use their theoretical knowledge of their specialty in non-language higher education institutions and in language schools on disciplines "Practical course of foreign language", "Foreign language for professional communication" (English), "Business Foreign Language" (English) and "Second Foreign Language" (French) in practice.

Thus, future specialists in the specialty "Management" or students of language schools in the study of relevant topics, perform design tasks: create a business plan for their own future of English.

They should:

- distribute the roles and functions of team members;

- invent the name and logo of the company, the location of the company;

- calculate the necessary sum for rent or purchase of premises, payroll, advertising, etc .;

- define goals, strategies, structure of the target audience;

- determine the personnel, their number and functions of the workers;

- develop an advertising campaign to spread information about the company;

- submit a presentation of the company;

- discuss and evaluate the company of their "competitors";

- vote for the best company.

In turn, students studying at the specialties "Hotel-restaurant business" and "Food Technology" and students studying the themes "In the restaurant", "In the hotel", etc., respectively, develop the business plan of their future hotel, restaurant, etc. The special attention should be paid to the interior and exterior of the hotel or restaurant, their atmosphere, uniforms of workers, etc.

Students studying the subject "Travel" or studying in the "Tourism" category, present a project of their excursion tour in English or French, which includes a travel route, a residence for business and economy class (hotels, hostels, apartments), restaurants and cafes where you can eat during your trip, transfer, flight, and more. Students need to calculate how much a trip will cost. The project is presented by students in the form of presentation protection. In addition, an example of a project for future tourism professionals is the development of a video tour of their hometown. Students choose interesting places, find information about them, translate it into a foreign language, take a video in English or French, in which they act as a guide. Students present a project at the classroom as a video clip or video presentation.

Future specialists in commodity research are developing their own project on the study of a particular product or product (ice cream, cheese, croissants, chocolate, water, milk, kefir, yogurt, tea, coffee, etc.). Applicants of higher education studying in language specialties, while teaching the topic "Shops", "Products" can also: 
- identify general characteristics and product features;

- learn the production process, its stages;

- consider useful properties and possible defects of the product;

- compare different types of products (their characteristics, quality, composition, taste, price, etc.);

- discover analogues of this product in the world, find interesting facts about the product;

- make a product presentation in groups or individually.

In the modern educational process of studying a foreign language, a lot of attention is paid to the use of video clips for classes in English in higher education institutions. This method involves the passivity of students when they are consumers of the finished product-educational video clips with the tasks offered to them. But modern education should move further, expanding its borders, going beyond the classics of teaching. Therefore, we can't deny the expediency of videos, which are part of the projects performed by the students themselves. It is possible to emphasize the practicality of this method, when taking their videos, students use knowledge of English in practice. In addition, this method pushes them to independence, improves their ability to work in a team, develops the creativity of students, makes the learning process more interesting and lively. From a passive consumer, students turn into active people who embody their creative ideas in life.

In our work we consider the examples of the method of recording video as an integral part of the process of learning English or any other foreign language. So, when studying the topic "mass media" or "the Internet", we offer students to film their video blog, which is undoubtedly relevant and popular in our society. Previously in class we read texts, perform tasks on the topic, watch videos, discuss well-known Internet bloggers. Why they became popular, which topics are relevant, what issues are discussed on blogs, what their target audience is. Students justify their choice which blogs are most interesting to them and why. Then, students are encouraged to make a layout of their video blog, to develop a concept, topics, methods of popularizing the blog, who video blogs will be directed on, and to make a pilot blog project in the classroom. At home, students have to make their video blogs, according to the developed concept. As experience shows, students have an extremely wide range of ideas and a rich creative potential that needs to be activated. They offered their video blogs in a variety of topics such as eco-blogs, handmade blogs, blogs for English language learning, blogs promoting their hometown, and more. It should be noted exalted infusion and activity, this task was performed with. At the next lesson, students demonstrated their videos, put questions to each other, offered their ideas about the materials they just looked at. This method can be used not only in classes on the practical course of the main foreign language, but also in classes on practical grammar. When studying any grammatical topic, students can be offered to remove a video, in the plot of which they explain a certain rule of the use of one or another time, a passive deposit, an indirect language, and others like that. Or they can overcome the practical use of problematic grammatical issues in a scene or mini film. As a rule, students accomplish this task with enthusiasm in large or small groups.

Conclusions. The scientific work is devoted to the problem of improving the English language learning process in higher education institutions through the implementation of the project method. Thus, the material presented allows us to make the following conclusion. The current state of education requires that English teachers direct the educational process to its practical use in everyday, business, professional speech. Of particular importance is the ability to combine professional knowledge with computer skills and a high level of foreign language skills. In today's educational process, it is rational to use a model that can appropriately combine traditional methods of teaching English with the latest computerized teaching methods. A similar form of teaching a foreign language will facilitate the formation of educational situations, in which the presentation, consolidation and activation of the material is made by the student in an independent form, and the creation of language skills and abilities is under the control of a teacher.

Summing up, it should be noted that the method of project has significant advantages over traditional methods of interaction with students and teachers. Higher education students are highly motivated and interested in the subject they are working on during the project. The teacher should direct and correct student activities, give some advice and inspire them. Joint action by students from teacher focused on the goal - the creation of the project, contribute to improved relations and better understanding between them.

Considering the above materials, it can be concluded that the use of video in teaching English allow virtually increase the use of oral speech not only in class but also after it. Filming of their videos is interesting for students, they help to master the material and use it in further classes, perform didactic and various developmental functions. Thus, the teacher becomes a mentor for independent learning, cognitive and creative activities of students. Thus, we conclude that the studying a foreign language can be made more lively, more interesting, it is better if the teacher uses the method of the project, which can involve multimedia presentations, drawings, illustrations, newspapers, magazines, maps, videos, programs, schemes, questionnaires, surveys, graphs and charts. When using this method of teaching higher education applicants remember the vocabulary units and grammatical structures, develop creative thinking, creativity and imagination.

\section{References:}

1. Arvanitopoulo E. G. Features of teaching a foreign language according to the project method. Bulletin of the Kiev National Linguistic University. Series of pedagogy and psychology. Vol. 5. K. : Publishing Center of KNLU, 2002. P. $230-232$. 
2. UMK "English in the focus" ("Spotlight-9") / Yu. E. Vaulin, J. Dully, O. I. S. Podlyako, V. Evans. M. : Education, Express Publishing, 2010. P. 15-17.

3. Glazkova N.O. Project technology in English lessons. URL: http://www.nbuv.gov.ua/portal/soc_gum/pfto/2010_6/files/ PD610 18.

4. Gusak T., Kobets M. Methodology of Teaching Foreign Languages. Native School. 2006. № 2. P. 58-60.

5. Yegorov O. Means and technologies of a single informational and educational space / ed. V. Yu. Bykov, Yu. O. Zhuk. K., 2004. $240 \mathrm{p}$.

6. Knyazyan M. Structure of information and technological competence and methodical aspects of its formation in future translators. Scientific Notes of the Kirovograd State Pedagogical University named after. V. Vinnichenko. Series "Philological Sciences". Issue 81 (2). View of the KDPU. Kirovograd, 2009. P. 337-340.

7. Kutse S. Modern methods of teaching foreign languages. URL: http://oldconf.neasmo.org.ua/node/757/.

8. Nagach M. V. Application of the method of projects in the study of foreign languages. URL: http://www.nbuv.gov.ua/portal// Soc_Gum/Vchdpu/ped/2012_101/Nagach.pdf.

9. Nosenko Y. L. Application of IT in education. Foreign languages at school. 2004. № 6. P. 9-11.

10. Oleinik I. Using the method of projects in English lessons. Proftehosvita. 2012. № 10 (46). P. $29-33$.

11. Polat E. S. Method of projects in the lessons of a foreign language. 2000. № 2. P. 3-10 ; № 3. P. 3-9.

12. Tsigankova S. O. On the choice of methods for designing educational process. Vysn. Lugansk nats ped un-th them Taras Shevchenko. Lugansk, 2007. № 9 : Ped. science. P. 207-215.

13. Ridell D. Teach English as a foreign language. London, 2012. 352 p.

14. Rogova G. V. Methods of teaching English. L., 1975. 312 p.

Грачова І. В., Ніконенко О. В. Обтрунтування використання методу проектів під час викладання англійської мови в закладах вищої освіти

Актуальність дослідження полягає в необхідності знайти найефективніші методи викладання англійської мови на практичних заняттях у закладах вищої освіти, завдяки чому можна поліпшити знання англійської мови в здобувачів вищої освіти, мотивувати їх до вивчення іноземної мови, підштовхнути до власного розвитку. Мета дослідження довести доцільність використання методу проектів під час викладання англійської мови в закладах вищої освіти для поліпшення навчально-виховного процесу й підвищення рівня володіння англійською мовою студентами, курсантами та слухачами. Завдання дослідження: дослідити теоретичні засади проблеми; розробити завдання для практичних занять з використанням методу проектів під час викладання англійської мови здобувачам вищої освіти; визначити дочільність використання методу проектів у навчальному процесі. Для обтрунтування теоретичних засад дослідження використано аналіз та узагальнення літературних джерел з теми, зокрема аналіз методів навчання англійської мови. У ході дослідження проаналізовано впровадження методу проектів у викладання англійської мови в закладах вищої освіти; виявлено потенціал ичього методу, обтрунтовано доцільність його використання на заняттях з англійської мови в закладах вищої освіти. Представлено характеристики методу проектів під час викладання іноземної мови, що може допомогти викладачам доцільно використовувати иі методи на практиці; на їх основі розроблено фрагменти занять, які можуть стати прикладами застосування викладачами колективних та індивідуальних проектів і досліджень на заняттях з англійської мови в закладах вищої освіти. Отже, доходимо висновку, щяо заняття з іноземної мови можуть бути проведені жвавіше, иікавіше, доцільніше, якщо викладачем використовуються метод проекту, у якому можуть бути задіяні мультимедійні презентаиії, рисунки, ілюстраиїі, газети, журнали, карти, відеоролики, програми, схеми, анкети, опитування, графіки й діаграми. Під час використання цьього методу навчання здобувачі вищої освіти мимоволі запам'ятовують актуальні одиничі вокабуляру $і$ граматичні структури, розвивають творче мислення, креативність та уяву.

Ключові слова: проектна методика, методика викладання, заклад вищьӧ освіти, професійне знання, розумова діяльність, ознаки, викладач, студент.

УДК 37.01

DOI https://doi.org/10.31392/NPU-nc.series5.2020.73-1.16

Гречуха В. $Г$.

\section{РОЛЬ ЛАТЕРАЛІЗАЦІЇ ФУНКЦЙ ГОЛОВНОГО МОЗКУ В ПРОЦЕСІ АДАПТАЦІї ДИТИНИ ДО НАВЧАННЯ У ШКОЛІ}

У статті порушуються теоретичні питання формування міжпівкульної взаємодії та латералізації функцій головного мозку в дитини, урахування яких, на думку автора, є однією з головних умов ефективної адаптації молодших школярів до школи. Наголошується, щу в нейропсихології дитячого віку аналіз формування міжпівкульної взаємодї є одним із пріоритетних напрямів, та акцентується на значущості процесів міжпівкульної взаємодії для мозкової організації специффічних людських форм адаптивної поведінки. Розглядаються три головні рівні організаиії міжпівкульної взаємодії в онтогенезі. На першому етапі (від внутрішньоутробного розвитку до 2-3 років) закладається базис для міжпівкульного забезпечення нейрофізіологічних, нейрогуморальних і нейрохімічних асиметрій, які лежать в основі соматичного, афективного й когнітивного статусу дитини. На ивому рівні вперше заявляють про себе глибинні нейробіологічні передумови майбутнього психофізіологічного “стилю” поведінки дитини. На другому етапі (від 3 до 7-8 років) активізуються міжсіпокампальні комісуральні системи, закріпляються та автоматизуються все основні 